Article

\title{
Rietveld Quantitative Phase Analysis of Oil Well Cement: In Situ Hydration Study at 150 Bars and $150{ }^{\circ} \mathrm{C}$
}

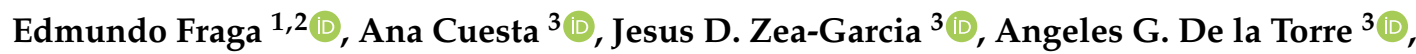 \\ Armando Yáñez-Casal ${ }^{2}$ and Miguel A. G. Aranda 1,3,*iD
}

1 ALBA Synchrotron, Carrer de la Lum, 2-26, Cerdanyola del Vallès, 08290 Barcelona, Spain; efraga@cells.es

2 Departamento de Ingeniería Industrial, Universidade da Coruña, Ferrol, 15403 A Coruña, Spain; armando.yanez@udc.es

3 Departamento de Química Inorgánica, Cristalografía y Mineralogía, Universidad de Málaga, 29071 Málaga, Spain; a_cuesta@uma.es (A.C.); jdavidzea@uma.es (J.D.Z.-G.); mgd@uma.es (A.G.D.1.T.)

* Correspondence: g_aranda@uma.es; Tel.: +34-952-131-992

Received: 9 May 2019; Accepted: 6 June 2019; Published: 12 June 2019

\begin{abstract}
Oil and gas well cements are multimineral materials that hydrate under high pressure and temperature. Their overall reactivity at early ages is studied by a number of techniques including through the use of the consistometer. However, for a proper understanding of the performance of these cements in the field, the reactivity of every component, in real-world conditions, must be analysed. To date, in situ high energy synchrotron powder diffraction studies of hydrating oil well cement pastes have been carried out, but the quality of the data was not appropriated for Rietveld quantitative phase analyses. Therefore, the phase reactivities were followed by the inspection of the evolution of non-overlapped diffraction peaks. Very recently, we have developed a new cell specially designed to rotate under high pressure and temperature. Here, this spinning capillary cell is used for in situ studies of the hydration of a commercial oil well cement paste at 150 bars and $150{ }^{\circ} \mathrm{C}$. The powder diffraction data were analysed by the Rietveld method to quantitatively determine the reactivities of each component phase. The reaction degree of alite was $90 \%$ after $7 \mathrm{~h}$, and that of belite was $42 \%$ at $14 \mathrm{~h}$. These analyses are accurate, as the in situ measured crystalline portlandite content at the end of the experiment, $12.9 \mathrm{wt} \%$, compares relatively well with the value determined ex situ by thermal analysis, i.e., $14.0 \mathrm{wt} \%$. The crystalline calcium silicates forming at $150 \mathrm{bars}$ and $150{ }^{\circ} \mathrm{C}$ are also discussed.
\end{abstract}

Keywords: high-pressure equipment; powder diffraction; synchrotron radiation; cement hydration; reactivity; oil well cement

\section{Introduction}

Portland cement (PC) is the most manufactured product in the world, as it is the main component of the construction industry [1]. In this paper, cement nomenclature will be used for describing the cement phases: $\mathrm{C}=\mathrm{CaO}, \mathrm{S}=\mathrm{SiO}_{2}, \mathrm{~A}=\mathrm{Al}_{2} \mathrm{O}_{3}, \mathrm{~F}=\mathrm{Fe}_{2} \mathrm{O}_{3}, \overline{\mathrm{S}}=\mathrm{SO}_{3}$, and $\mathrm{H}=\mathrm{H}_{2} \mathrm{O}$. PC is a multimineral material [2] containing $\sim 65 \mathrm{wt} \%$ of $\mathrm{C}_{3} \mathrm{~S}$ or alite; $15 \mathrm{wt} \%$ of $\mathrm{C}_{2} \mathrm{~S}$ or belite; $\sim 15 \mathrm{wt} \%$ of $\mathrm{C}_{4} \mathrm{AF}$ or tetracalcium aluminoferrite, and $\sim 5 \mathrm{wt} \%$ of $\mathrm{C}_{3} \mathrm{~A}$ or tricalcium aluminate (ideal stoichiometries: $\mathrm{Ca}_{3} \mathrm{SiO}_{5}, \mathrm{Ca}_{2} \mathrm{SiO}_{4}, \mathrm{Ca}_{4} \mathrm{Al}_{2} \mathrm{Fe}_{2} \mathrm{O}_{10}$ and $\mathrm{Ca}_{3} \mathrm{Al}_{2} \mathrm{O}_{6}$, respectively). Additionally, calcium sulphates are added to regulate the setting of the pastes/mortars/concretes.

The hydration of PC basically consists of two set of reactions (that interact with each other): the silicate reactions and the aluminate reactions [3]. $C_{3} S$ is the most important phase in PC. Under normal conditions of pressure and temperature, the hydration reaction of $C_{3} S$ [4] consists of its dissolution and 
the precipitation of a nanocrystalline calcium-silicate-hydrate (C-S-H) gel, and crystalline portlandite, $\mathrm{CH}$, according to reaction 1 . $\mathrm{C}-\mathrm{S}-\mathrm{H}$ gel is a complex hierarchically arranged material with overall chemical stoichiometry close to $(\mathrm{CaO})_{1.8} \mathrm{SiO}_{2} \cdot 4 \mathrm{H}_{2} \mathrm{O}$, which can be broken down at the nanoscale as $\left[\mathrm{Ca}_{1.2} \mathrm{SiO}_{3.1}(\mathrm{OH})_{2} \cdot \mathrm{H}_{2} \mathrm{O}\right] \cdot\left[\mathrm{Ca}(\mathrm{OH})_{2}\right]_{0.6} \cdot\left[\mathrm{H}_{2} \mathrm{O}\right]_{2.3}$ to describe its three main intermixed components [4]: [defective clinotobermorite].[nano-sized calcium hydroxide layers].[gel pore water. The reaction of belite is slower, yielding $\mathrm{C}-\mathrm{S}-\mathrm{H}$ gel and 0.2 moles of portlandite.

$$
\mathrm{C}_{3} \mathrm{~S}+5.2 \mathrm{H} \rightarrow 1.2 \mathrm{CH}+\mathrm{Ca}_{1.8} \mathrm{SH}_{4}
$$

In addition, at ambient conditions, the aluminate reaction consists of the dissolution of aluminates, i.e., $\mathrm{C}_{3} \mathrm{~A}$ and $\mathrm{C}_{4} \mathrm{AF}$ and calcium sulphate sources, to yield mainly crystalline ettringite (also known as $\mathrm{AFt}$ ), according to reaction 2 . In the absence of sulphates, monosulphoaluminate phases form like Kuzelite, $\mathrm{Ca}_{4} \mathrm{Al}_{2}(\mathrm{OH})_{12} \mathrm{SO}_{4} \cdot 6 \mathrm{H}_{2} \mathrm{O}$.

$$
\mathrm{C}_{3} \mathrm{~A}+3 \mathrm{C} \overline{\mathrm{S}} \mathrm{H}_{2}+26 \mathrm{H} \rightarrow \mathrm{C}_{6} \mathrm{~A} \overline{\mathrm{S}} \mathrm{H}_{32}
$$

On the other hand, Oil-Well-Cement (OWC) is a special kind of cement [5] used for specific applications mainly in oil, gas and geothermal industries. The pastes derived from OWC are subjected to high pressures (up to 1000 bar) and high temperatures (up to $300^{\circ} \mathrm{C}$ ) during curing. Consequently, the hydration processes changes substantially, and the hydration phases formed under these conditions are different (or they can be) than those obtained at room temperature and atmospheric pressure $[6,7]$. Based on previous studies [7-9], it is evident that the effect of temperature is larger than that of pressure in cement hydration. Although there are many studies of cement hydration at high temperature, there are not many in situ diffraction works focused on the combined role of pressure and temperature on cement hydration. Furthermore, these studies were qualitative or semi-quantitative as they mainly followed selected diffraction peaks [see for instance [10] and references therein]. These studies were mainly dedicated to the hydration of $C_{3} S[6,7,11,12]$.

High pressures increase the hydration rate [11] of a cement, mainly the hydration kinetics of $\mathrm{C}_{3} \mathrm{~S}$ [6]. Moreover, it was found that the length of the induction period, very much related to the time required for initial setting, is reduced as the pressure and temperature increases $[6,7,11]$. However, high temperature and high pressure also lead to the formation of different hydrated products. For instance, it has been reported that C-S-H gel is not stable at high temperature [11] and it (partially) reacts/decomposes resulting in other (crystalline) hydrates, such as $\alpha-\mathrm{C}_{2} \mathrm{SH}$ and/or Jaffeite, $\mathrm{C}_{6} \mathrm{~S}_{2} \mathrm{H}_{3}$. An ex situ hydrothermal study [13] also showed that at high temperature the C-S-H and ettringite phases were decomposed into Jaffeite via $\alpha-\mathrm{C}_{2} \mathrm{SH}$ and monosulphate, respectively. Furthermore, the formation of these hydrated phases under high pressure and temperature conditions leads to poor mechanical properties and pore structure degradation. Consequently, some authors [14,15] employed different additives, for instance, silica fume or blast furnace slag, to try to inhibit the crystallization of those non-desired crystalline calcium silicates hydrates. It seems that the use of additives lead to an improvement in the microstructure of these pastes resulting in the enhancement of mechanical properties [16]. However, much research is still required to clarify these observations and to establish proper correlations between phase development, microstructure and mechanical properties [17].

Synchrotron X-ray powder diffraction can be used to follow in real time the in situ hydration reaction [18] because it is possible to select an X-ray beam of high energy (which enables penetration of the cell component(s)) and with very high flux (which yields a good signal-to-noise ratio in the diffraction data). For this study, we have used a home-made high pressure and high temperature spinning capillary cell [19] which has been successfully operated up to 200 bars and $200{ }^{\circ} \mathrm{C}$. This cell is an evolution of a previous one [20] but with a new design that allows the capillary to spin in order to increase particles statistics with the final goal to carry out quantitative phase analyses. This capillary cell makes it possible to collect in situ X-ray powder diffraction data of hydrating cements to 
be analysed by Rietveld methodology. The quality of a single Rietveld quantitative phase analysis was already checked in a previous study reporting the cell design and operation [19].

The main objective of this work was to demonstrate that in situ X-ray powder diffraction data collected from the new capillary cell is of sufficient quality to carry out quantitative phase analyses, and not only to follow selected diffraction peaks. This is illustrated by the study of the hydration of an OWC under 150 bars and $150^{\circ} \mathrm{C}$, where the in situ diffraction data have been analysed by the Rietveld method in order to understand the hydration kinetics and the phase development. The amounts of the initial phases and the formed components are reported up to $14 \mathrm{~h}$ of hydration.

\section{Materials and Methods}

\subsection{Sample Preparation}

A commercial OWC Class G, high sulfate resistant HSR, (Dyckerhoff-Lengerich, Lengerich, Germany) was used for this work. The elemental composition is given in Table S1, as Supplementary Materials. This cement has a Blaine fineness value of $340 \mathrm{~m}^{2} / \mathrm{kg}$, the Brunauer-Emmett-Teller BET specific surface measured by $\mathrm{N}_{2}$ sorption was 0.88 (1) $\mathrm{m}^{2} / \mathrm{g}$ and the Particle Size Distribution (PSD) was measured using a laser analyser (Mastersizer S, Malvern, UK). The hydration of the OWC was performed by adding water to the powder sample at a water/cement mass ratio of 0.47 . Then, the mixture was stirred by hand in a plastic beaker for $2 \mathrm{~min}$. The paste was immediately loaded, with the aid of a syringe and a short piece of silicone tubing, into the sapphire capillaries (Saint-Gobain crystals) with outer and inner diameters of $3.18 \mathrm{~mm}$ and $1.75 \mathrm{~mm}$, respectively. Polytetrafluoroethylene PTFE cylindrical plugs of $2 \mathrm{~mm}$ of length and $1.75 \mathrm{~mm}$ outside diameter (with tolerance for its width smaller than $0.1 \mathrm{~mm}$ ) were used to block both ends of the sapphire capillaries at least at $10 \mathrm{~mm}$ from the end of the capillary. These flexible plugs allow the pressure from the oil system to be transmitted from both sides.

\subsection{Laboratory Initial Characterization}

Thermal analysis measurement of the final paste (after the synchrotron experiment) was performed in a SDT-Q600 analyzer (TA instruments, New Castle, DE, USA) under a flow of dry air. The initial and final setting times were determined from Vicat-methodology following UNE-EN 196-3:2005. The isothermal calorimetric study was performed in an eight channel Thermal Activity Monitor (TAM) instrument using glass ampoules. The heat flow was collected up to 3 days at $20^{\circ} \mathrm{C}$.

\subsection{Synchrotron X-ray Powder Diffraction (SXRPD) Experiment}

Full details about the beamline, capillary cell and experimental conditions have been very recently reported [19]. Here, we provide a summary for convenience. A photon energy of $20 \mathrm{keV}$ $(\lambda=0.62278 \AA$ A $)$ was selected with a Si (111) channel-cut monochromator to collect powder diffraction data in Debye-Scherrer configuration. The beam size was $0.8 \mathrm{~mm}$ vertical and $1.2 \mathrm{~mm}$ horizontal. The detector was a LX255-HS Rayonix CCD placed at $313 \mathrm{~mm}$ from sample (tilt vertical angle of $28.92^{\circ}$ ).

A sapphire capillary fill of quartz was used as the standard to calibrate the detector setup. The sealed sapphire capillary containing the paste was loaded into the spinning capillary cell. Firstly, the static pressure was manually generated by a pump generator to achieve 150 bars. Subsequently, the heating system was turned on to reach $150{ }^{\circ} \mathrm{C}$. It has to be borne in mind that the pressure application took place $46 \mathrm{~min}$ after paste mixing and the desirable temperature was reached $20 \mathrm{~min}$ later. The initial $46 \mathrm{~min}$ of hydration occurred at room temperature and pressure. Consequently, it is considered here as initial time, $\mathrm{t}_{0}$, the time in which the desired pressure was reached, it means $46 \mathrm{~min}$ after initial water-cement mixing time. This criterion is followed in the text, tables and figures.

The cell was rotated at $240 \mathrm{rpm}$. It contains a Micos LS-180 translation stage that enables to collect $2 \mathrm{D}$ data in any desired horizontal point of the capillary. To ensure that representative datasets are taken, snapshots at 5 different positions along the capillary, at $0.5 \mathrm{~mm}$ intervals, were acquired with an 
exposure time of two seconds per snapshots. The first hydrating in situ pattern was collected $9 \mathrm{~min}$ after reaching the selected pressure (i.e. during heating). Then, patterns were collected with intervals of $\sim 15 \mathrm{~min}$ for $14 \mathrm{~h}$. The 2D images were reduced to $1 \mathrm{D}$ data by pyFAI software (version: 0.10 .3 , European Synchrotron Radiation Facility, ESRF, Grenoble, France) [21] and the five 1D raw patterns, collected at different capillary positions, were sum up with a local software yielding the final dataset to be analysed by Rietveld methodology.

\subsection{SXRPD Data Analysis}

The regions of the powder diffraction patterns which include the Sapphire diffraction peaks were excluded for the fits. Generalized Structure Analysis System (GSAS) suite of programs [22] were used to analyse all powder patterns to obtain Rietveld quantitative phase analyses (RQPA). The references for the crystal structures used to calculate the powder patterns are given in Table 1. Final global refined parameters were background coefficients, zero-shift error, cell parameters and peak shape parameters using a pseudo-Voigt function [23].

\section{Results and Discussion}

\subsection{Initial OWC Characterization}

As expected for a G-type OWC, the alkaline content $\left(\mathrm{K}_{2} \mathrm{O}\right.$ and $\left.\mathrm{Na}_{2} \mathrm{O}\right)$ was smaller than $0.8 \mathrm{wt} \%$, see Table S1. The RQPA for this cement was previously reported [19]. Also, as expected, the $\mathrm{C}_{3} \mathrm{~A}$ content measured by Rietveld method from $X$-ray laboratory data was low. On the other hand, fineness is as important as the phase composition to understand the kinetic of the reactions at early ages as these strongly depends upon the particle sizes. Therefore, the PSD curve for this OWC is shown in Figure S1. The average particle size, $d v, 50$, was $13 \mu \mathrm{m}$ and dv, 90, was $38 \mu \mathrm{m}$.

In order to gain further insight into the early age reactivity of this cement, some ambient tests were carried out. It was not possible to determine the setting time for a paste with a water-to-cement $(\mathrm{w} / \mathrm{c})$ mass ratio of 0.47 due to bleeding. Therefore, a second paste with $\mathrm{w} / \mathrm{c}=0.35 \mathrm{was}$ used for the Vicat measurement. For the paste with w/c mass ratio of 0.35 , the initial setting was $388 \mathrm{~min}$ and the final setting was slightly larger than $550 \mathrm{~min}$. A calorimetric study was also carried out for these two pastes (w/c ratios of 0.35 and 0.47 ). Figure $\mathrm{S} 2$ displays the calorimetric data showing the maxima of the heat flow at 13 and $18 \mathrm{~h}$ for the pastes with w/c ratios of 0.35 and 0.47 , respectively. These data were collected at $20^{\circ} \mathrm{C}$ and room pressure and much faster kinetics are expected at 150 bars and $150{ }^{\circ} \mathrm{C}$, see below.

\subsection{Qualitative Study}

Figure S3 displays 2D raw patterns for the initial (anhydrous) OWC, the paste hydrated at $1 \mathrm{~h}$ and $38 \mathrm{~min}$ and at $11 \mathrm{~h}$ and $22 \mathrm{~min}$, as representative examples. Five of these snapshots were summed to give a representative 1D SXRPD pattern at a given hydration time. Figure 1 displays a 3D view of the one-dimensional SXRPD patterns collected every $15 \mathrm{~min}$ at 150 bars and $150{ }^{\circ} \mathrm{C}$. The qualitative phase evolution can be derived from the evolution of the diffraction peaks. This is useful for quantitative analyses of estimations of the appearance of new phases, as described in the next section. From this plot can be stated that alite has almost fully reacted within the first $7 \mathrm{~h}$ of hydration. 


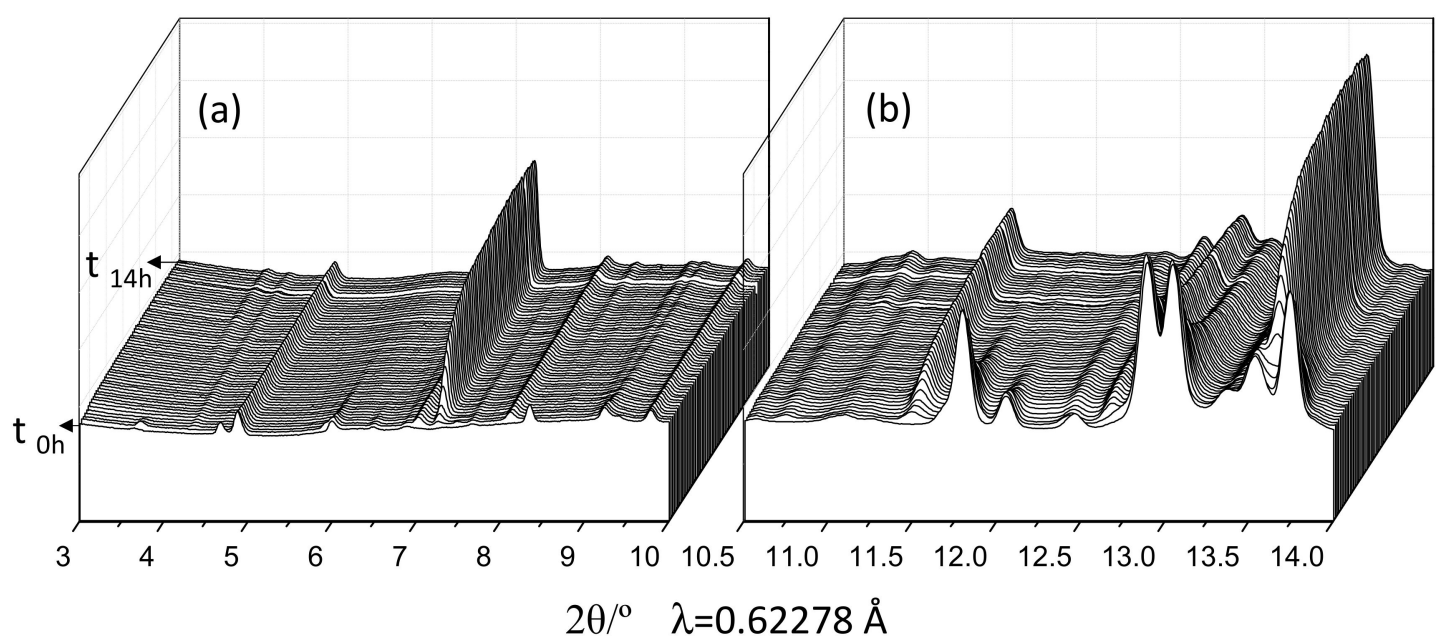

Figure 1. 3D view of the SXRPD raw patterns for the OWC paste collected at 150 bars and $150{ }^{\circ} \mathrm{C}$ every $15 \mathrm{~min}$ of hydration up to $14 \mathrm{~h}$. (a) Region from 3.0 to $10.0^{\circ}(2 \theta)$ and (b) region from 10.5 to $14.0^{\circ}(2 \theta)$.

A better look for the evolution of the component phases can be obtained by selecting appropriated time windows. Figure 2 shows 1D SXRPD patterns for OWC pastes during the first $2 \mathrm{~h}$ of hydration at 150 bars and $150{ }^{\circ} \mathrm{C}$. In the pattern collected at $26 \mathrm{~min}$, the diffraction peaks from gypsum vanished and the main diffraction peak of bassanite $\left(5.9^{\circ}[2 \theta / \lambda=0.62278 \AA]\right)$ appeared, indicating the partial dehydration of gypsum in these conditions. At this early reaction time it can be also observed that the AFt reflection, located at $3.7^{\circ}$, starts to decrease and vanished about $38 \mathrm{~min}$. This is mainly due to the temperature as ettringite decomposes at temperatures above $\sim 80^{\circ} \mathrm{C}$. Moreover, katoite starts to precipitate at very early hydration ages, after $26 \mathrm{~min}$ in these conditions. Figure 2 also shows that alite starts to dissolve close to $26 \mathrm{~min}$ but the diffraction peaks of crystalline portlandite are barely visible at this hydration age. The portlandite appearance can be inferred from its diffraction peak located at $7.2^{\circ}$, which is clearly visible at $32 \mathrm{~min}$ of hydration; its formation accelerates after one hour.

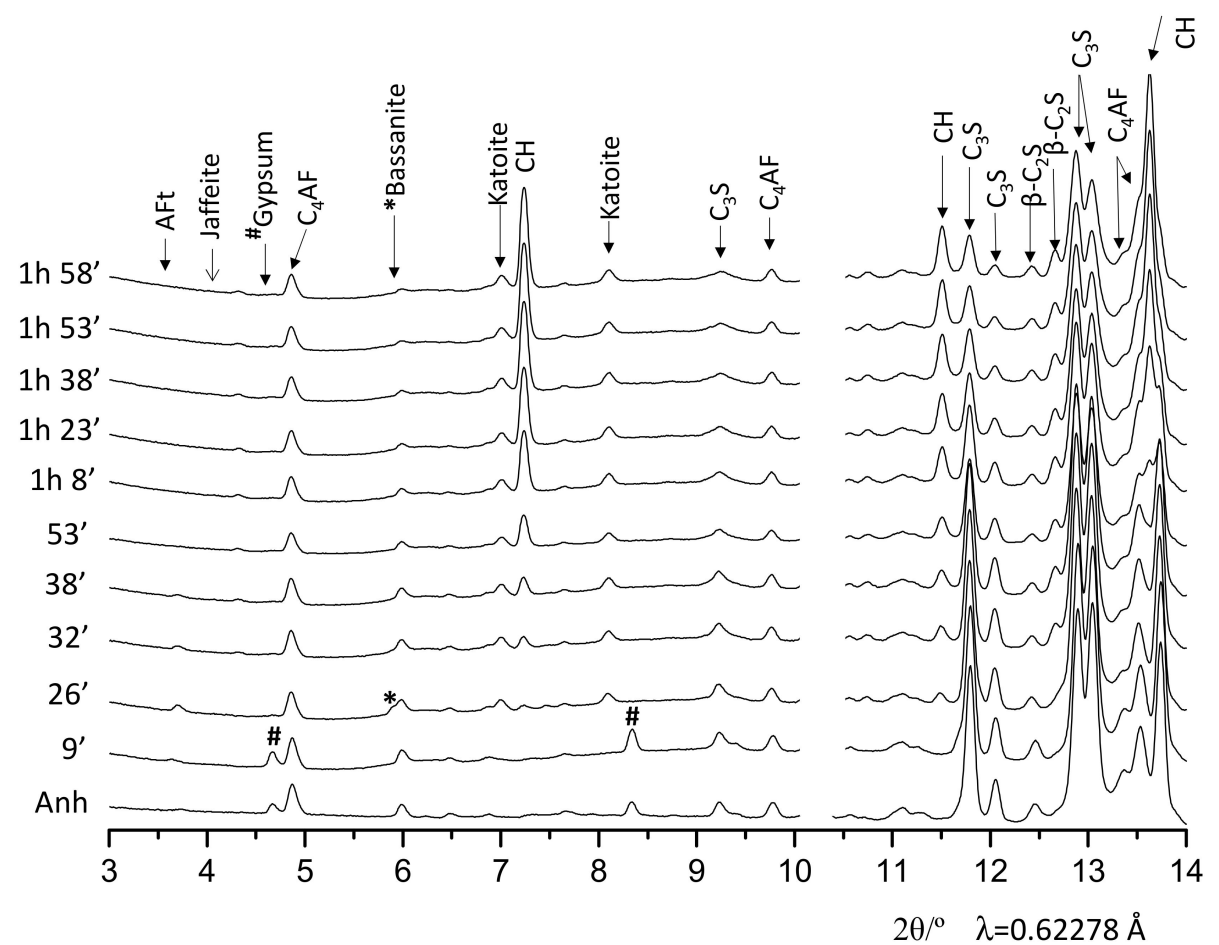

Figure 2. Selected range of SXRPD raw patterns for the OWC paste collected at 150 bars and $150{ }^{\circ} \mathrm{C}$ at early hydration ages (up to $2 \mathrm{~h}$ ), with the main diffraction peaks due to a given phase labelled. 
Figure 3 shows 1D SXRPD patterns for OWC pastes for up to $14 \mathrm{~h}$ of hydration. In this figure, it can be highlighted the formation of crystalline hydrated phases that are not common at room temperature and pressure, such as $\alpha-\mathrm{C}_{2} \mathrm{SH}$ and Jaffeite. It seems that the formation of $\alpha-\mathrm{C}_{2} \mathrm{SH}$ starts close to $7 \mathrm{~h}$ of hydration and the formation of a very small amount of Jaffeite takes place after $11 \mathrm{~h}$ of hydration. It is also worth noting that $\mathrm{C}_{2} \mathrm{~S}$ phase starts to react at later ages. This can be observed by following the main (non-overlapped) diffraction peak of $\mathrm{C}_{2} \mathrm{~S}$ located at $12.4^{\circ}$. Finally, it must be highlighted that the main diffraction hump/peak of C-S-H gel, located at $\sim 12^{\circ}$, is not present which indicates that the crystallinity of the gel (in these conditions) is very low. This peak is overlapped with the diffraction peak of calcite which allows one to rule out carbonation of the pastes and it is also an indirect evidence of the tightness of the system.

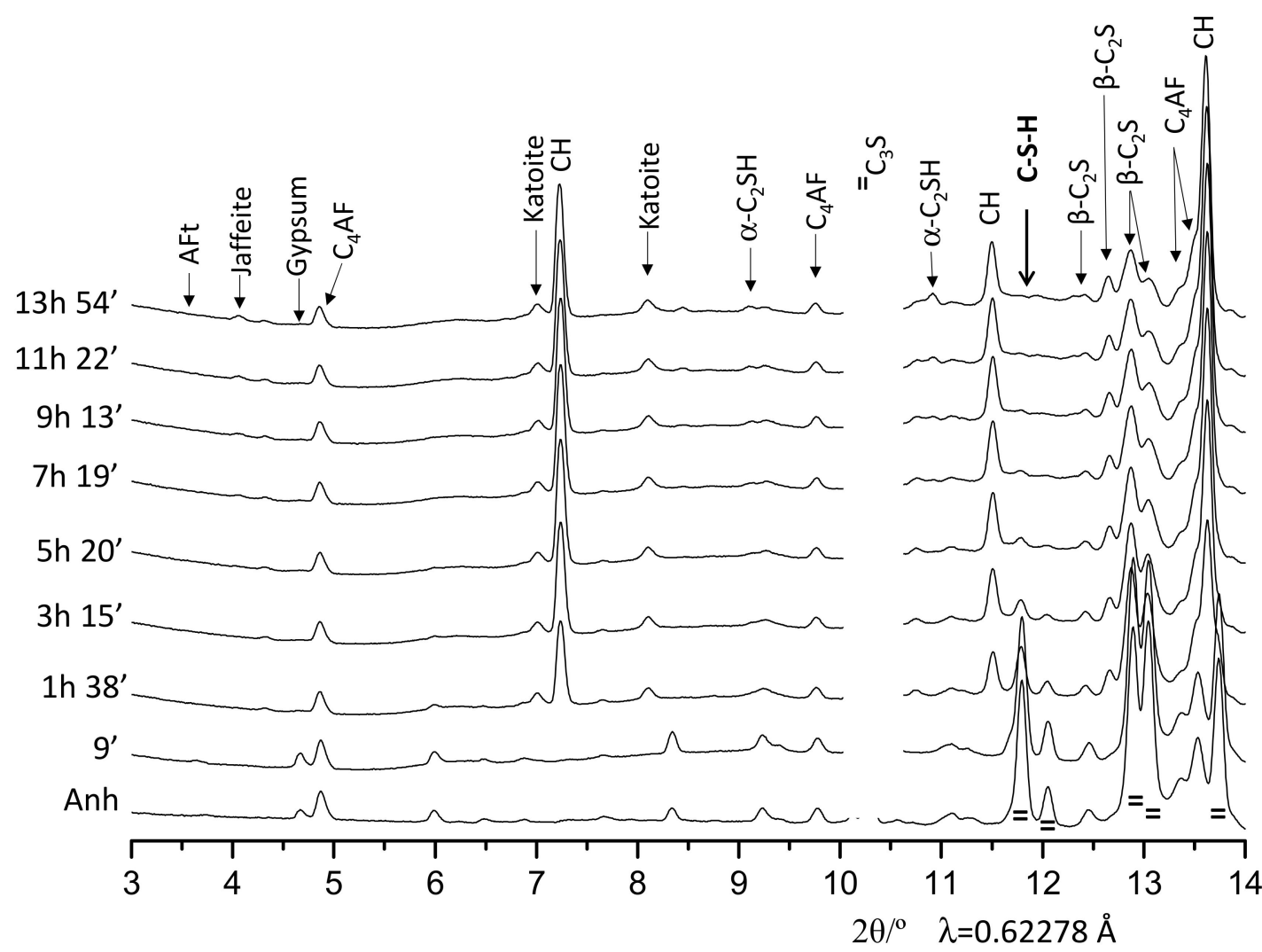

Figure 3. Selected range of SXRPD raw patterns for the OWC paste collected under 150 bars and $150{ }^{\circ} \mathrm{C}$ at late hydration ages (up to $14 \mathrm{~h}$ ), with the main diffraction peaks due to a given phase labelled.

\subsection{Quantitative Phase Analyses}

Spinning of the capillary resulted in accurate powder diffraction intensities for the in situ recorded powder diffraction patterns. This statement is supported by the quality of the Rietveld fits, which make it possible to quantitatively determine the phase contents at the different hydration times; see below. Rietveld methodology, without the addition of an internal standard [24], does not allow determinations of the overall amount of amorphous and crystalline not-quantified ( $\mathrm{ACn}$ ) content to be made without assumptions. Here, it was decided not to add an internal standard because it was not known if (i) it could react with component(s) of the paste under high temperature and pressure, (ii) it could modify the kinetic of the reactions by providing additional surface for crystallization and precipitation (filler effect). Research is needed to establish whether an appropriate internal standard can be used under these (demanding) conditions. On the other and, external standard methodology is being widely used in reflection geometry. However, for capillary transmission geometry, the situation is more complex as the packing degree of the standard and the sample, within the capillaries, must be the same or known with precision. Furthermore, the time-evolution of the packing degree (under pressure and 
temperature) must be the same (or at least known). Again, research on to this subject is needed to determine whether external standard methodology can be used here.

RQPA have been carried out as described in the experimental section, i.e., following the same procedures developed for ex situ recorded data [24-26]. Figure 4 displays two Rietveld plots at selected hydration times, $\sim 2$ and $\sim 11 \mathrm{~h}$. The quality of the fits is very good as ensured by the flatness of the difference curves (blue lines at the bottom of each panel). Direct RQPA results are shown in Table S2. In addition to the phase contents, that table also gathers the values for the Rietveld disagreement factor $\left(R_{W P}\right)[25]$ of all the fits. The values are low, indicating good agreement between the data and the model but $R_{W P}$ values can also be low because the background values are relatively high. Therefore, Table S2 also reports the $\mathrm{R}_{\mathrm{F}}$ values [25] for alite, which only depend upon the quality of the data and the appropriateness of the structural description. The low values of $R_{F}$ also indicate the good quality of the in situ diffraction data.

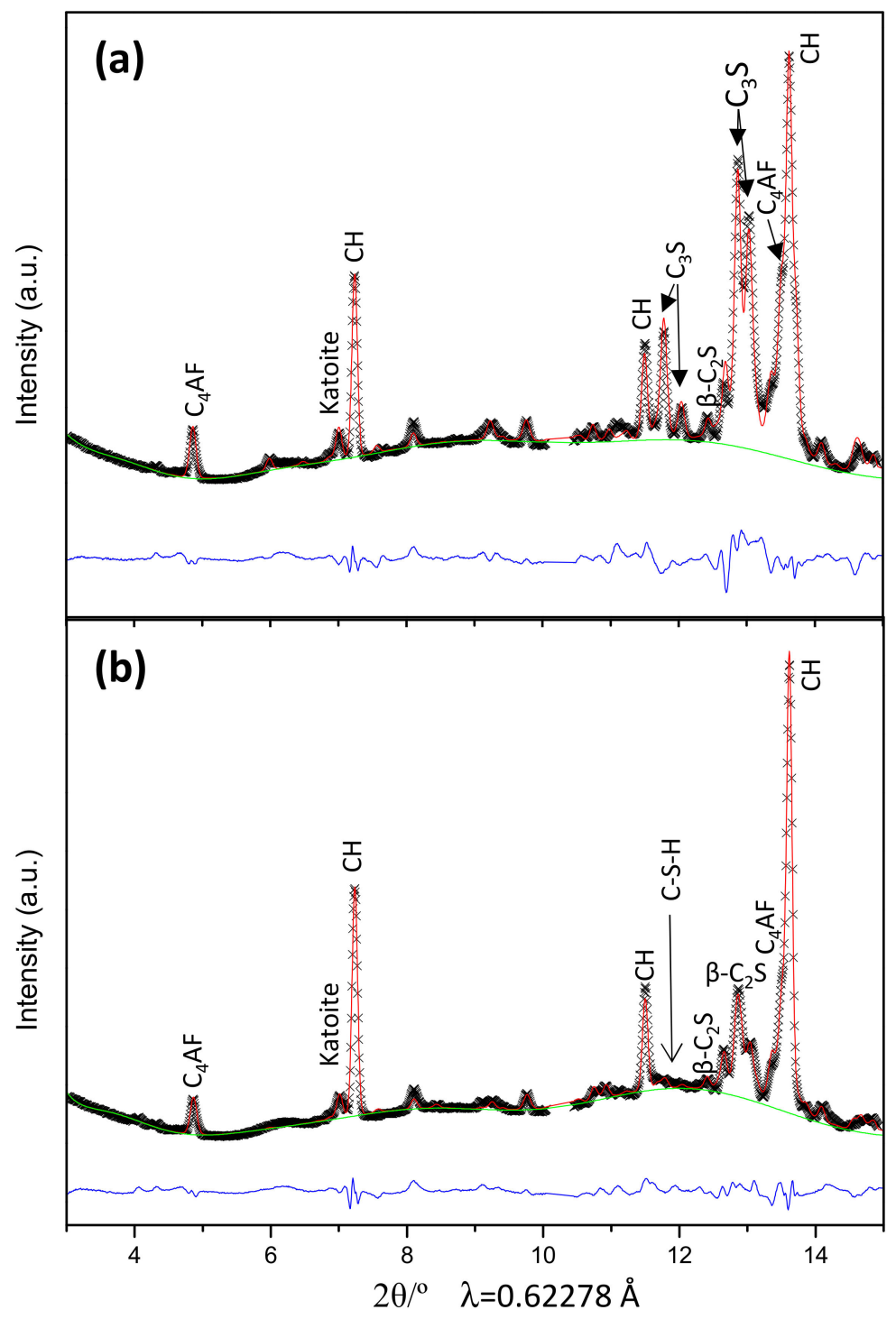

Figure 4. In situ Rietveld synchrotron powder X-ray diffraction plots for the oil well cement paste hydrating under 150 bars and $150^{\circ} \mathrm{C}$ for (a) $1 \mathrm{~h}$ and $38 \mathrm{~min}$, and (b) $11 \mathrm{~h}$ and $22 \mathrm{~min}$.

As stated above, ACn contents cannot be determined from the acquired data without assumptions being made [27]. However, if one (or more) component phases do not react, they can be used as standard to determine the overall amount of $A C n$. Belite $\left(C_{2} S\right.$ phase), which from Figure 1 , Figure 2 does not seem to react up to $3 \mathrm{~h}$ and $15 \mathrm{~min}$ of hydration, was used as standard up to this hydration 
time. Hence, it is assumed here that the amount of belite do not change from $\mathrm{t}_{0}$ to $3 \mathrm{~h}$ and $15 \mathrm{~min}$. Additionally, $\mathrm{C}_{4} \mathrm{AF}$ phase does not seem to react from $5 \mathrm{~h}$ and $20 \mathrm{~min}$ up to $14 \mathrm{~h}$ as their diffraction peaks do not decrease in intensity, see Figures 1 and 3. Therefore, it is also assumed here that the content of $\mathrm{C}_{4} \mathrm{AF}$ do not change from $5 \mathrm{~h}$ and $20 \mathrm{~min}$ to the end of the experiment. A recent publication reported the low reactivity of this phase at high temperature and pressure [17]. Under these constraints, the ACn contents can be calculated; the full quantitative phase analyses are reported in Table 1 and displayed in Figure 5. For time $=0, \mathrm{ACn}$ is just the added free water, as it is assumed here that the OWC does not contain any amorphous fraction. Furthermore, as this is a quantitative study, the remaining free water and the overall amount of amorphous solid content can be derived from ACn values after the chemically bounded water is estimated, see Table 1 . The chemically bounded water was estimated from reactions (1)-(3) assuming a katoite stoichiometry of $\mathrm{Ca}_{2.93} \mathrm{Al}_{1.97}\left(\mathrm{SiO}_{4}\right)_{0.64}(\mathrm{OH})_{9.44}$.

$$
\mathrm{C}_{2} \mathrm{~S}+4.2 \mathrm{H} \rightarrow 0.2 \mathrm{CH}+\mathrm{Ca}_{1.8} \mathrm{SH}_{4}
$$

Figure 5 and Table 1 show the quantitative evolution of the different component phases over time. Firstly, the evolution of the anhydrous phases will be discussed. Alite starts to react very quickly; at 9 min after reaching the selected pressure, a decrease in percentage is noticeable. After $7 \mathrm{~h}$, its content has decreased by $90 \%$, being below $4 \mathrm{wt} \%$. Remarkably, belite starts to react after $5 \mathrm{~h}$ and the degree of reaction of this phase is $\sim 42 \%$ after $14 \mathrm{~h}$ of hydration. To the best of our knowledge, the in situ reactivity of belite has not been reported in any OWC powder diffraction study, as their diffraction peaks are strongly overlapped with those of alite. As expected, the dissolution/reactivity of $C_{3} A$ is very fast and this phase is totally consumed in less than $1 \mathrm{~h}$ of hydration. Finally, the reactivity of $\mathrm{C}_{4} \mathrm{AF}$ phase is very peculiar. It reacts at early ages, see Table 1 and Figure 5, about $28 \%$ up to $3 \mathrm{~h}$ and then its reactivity is inhibited. The hydration of this phase under high temperature and pressure deserves more research.

Table 1. Re-normalized RQPA for the OWC paste hydrated under 150 bars and $150{ }^{\circ} \mathrm{C}$. Amorphous content determination is also included, obtained by internal standard methodology, considering $\beta-C_{2} S$ as standard up to $3 \mathrm{~h}$ and $15 \mathrm{~min}$ and $\mathrm{C}_{4} \mathrm{AF}$ afterward. The numbers in bold highlight the assumption of no reaction of these phases in the reported time intervals.

\begin{tabular}{|c|c|c|c|c|c|c|c|c|c|c|c|}
\hline Phase/wt $\%$ & $\mathbf{t}_{0}$ & $9^{\prime}$ & $26^{\prime}$ & $53^{\prime}$ & $1 \mathrm{~h} 38^{\prime}$ & $3{\mathrm{~h} 15^{\prime}}^{\prime}$ & $5 \mathrm{~h} 20^{\prime}$ & 7 h $19^{\prime}$ & $9 \mathrm{~h} \mathrm{13}^{\prime}$ & 11 h $22^{\prime}$ & 13 h $54^{\prime}$ \\
\hline $\mathrm{C}_{3} \mathrm{~S}[28]$ & $41.6(1)$ & $40.1(1)$ & $34.6(1)$ & $29.9(1)$ & $15.6(2)$ & $8.2(2)$ & $4.9(3)$ & $3.3(2)$ & $2.5(3)$ & $2.1(3)$ & $1.5(3)$ \\
\hline$\beta-C_{2} S$ [29] & $9.9(2)$ & $9.9(-)$ & $9.9(-)$ & $9.9(-)$ & $9.9(-)$ & $9.9(-)$ & $9.1(3)$ & $8.6(3)$ & $7.8(3)$ & $6.9(3)$ & $5.8(3)$ \\
\hline $\mathrm{C}_{4} \mathrm{AF}[30]$ & $11.3(1)$ & 11.1(1) & $9.0(1)$ & 9.1(1) & $8.1(2)$ & $8.1(-)$ & $8.1(-)$ & $8.1(-)$ & $8.1(-)$ & $8.1(-)$ & $8.1(-)$ \\
\hline $\mathrm{o}-\mathrm{C}_{3} \mathrm{~A}[31]$ & $2.3(1)$ & $2.2(1)$ & $1.1(1)$ & 0.0 & 0.0 & 0.0 & 0.0 & 0.0 & 0.0 & 0.0 & 0.0 \\
\hline $\mathrm{C} \overline{\mathrm{S}} \mathrm{H}_{2}$ [32] & $2.9(2)$ & $3.1(1)$ & 0.0 & 0.0 & 0.0 & 0.0 & 0.0 & 0.0 & 0.0 & 0.0 & 0.0 \\
\hline $\mathrm{C} \overline{\mathrm{S}} \mathrm{H}_{0.5}$ [33] & 0.0 & 0.0 & $1.1(1)$ & 0.0 & 0.0 & 0.0 & 0.0 & 0.0 & 0.0 & 0.0 & 0.0 \\
\hline $\mathrm{CH}[34]$ & 0.0 & 0.0 & $0.3(1)$ & $3.0(1)$ & $7.2(1)$ & 10.1(1) & $11.6(1)$ & $12.4(1)$ & $12.8(1)$ & $12.8(1)$ & $12.9(1)$ \\
\hline AFt [35] & 0.0 & $0.6(1)$ & $0.6(1)$ & 0.0 & 0.0 & 0.0 & 0.0 & 0.0 & 0.0 & 0.0 & 0.0 \\
\hline Jaffeite [36] & 0.0 & 0.0 & 0.0 & 0.0 & 0.0 & 0.0 & 0.0 & 0.0 & 0.0 & 0.0 & $0.3(2)$ \\
\hline Katoite [37] & 0.0 & 0.0 & $3.5(1)$ & $5.8(2)$ & $6.0(2)$ & $6.4(2)$ & $6.5(2)$ & $6.6(2)$ & $6.5(2)$ & $6.3(2)$ & $6.2(2)$ \\
\hline$\alpha-\mathrm{C}_{2} \mathrm{SH}[38]$ & 0.0 & 0.0 & 0.0 & 0.0 & 0.0 & 0.0 & 0.0 & $0.2(3)$ & $0.6(3)$ & $1.1(3)$ & $2.1(3)$ \\
\hline $\mathrm{FW}^{\$}$ & $32.0(-)^{\#}$ & 31.2 & 26.3 & 21.9 & 16.0 & 12.9 & 11.2 & 10.2 & 9.6 & 9.0 & 8.3 \\
\hline Amorph. ${ }^{\#}$ & & 1.7 & 13.5 & 20.4 & 37.2 & 44.3 & 48.6 & 50.7 & 52.1 & 53.7 & 54.7 \\
\hline
\end{tabular}

${ }^{\$} \mathrm{FW}$ is estimated by subtracting the calculated chemically bounded water from the added water. ${ }^{\#}$ It is assumed that the OWC does not contains amorphous fraction and so the $w / c$ mass ratio of 0.47 corresponds to $32 \mathrm{wt} \%$ of free water ( $47 \mathrm{~g}$ of water in $147 \mathrm{~g}$ of paste). The overall amorphous solid content is determined by subtracting the free water from the ACn values.

The crystallization of portlandite starts $\sim 30 \mathrm{~min}$ and its acceleration takes place between 1 and $4 \mathrm{~h}$ of hydration. At $14 \mathrm{~h}$, the portlandite content was $12.9 \mathrm{wt} \%$, see Table 1 . The accuracy of these analyses can be estimated through a back of the envelope calculation following the chemical reactions described in the introduction. As the reactivity of alite and belite have been measured, the expected amount of the formed portlandite can be obtained. The resulting number is $16.0 \mathrm{wt} \%\left(15.6 \mathrm{wt} \%\right.$ from $\mathrm{C}_{3} \mathrm{~S}$ and $0.4 \mathrm{wt} \%$ from $\mathrm{C}_{2} \mathrm{~S}$ ). The theoretically expected portlandite content, $16 \mathrm{wt} \%$, is larger than the measured value, $12.9 \mathrm{wt} \%$, because portlandite is consumed by some of the crystalline products formed at high 
temperature and pressure and discussed below. Furthermore, the paste after this in situ study was extracted from the capillary, and a thermal analysis study was carried out to independently quantify the overall amount of portlandite. This study was carried out just after the synchrotron experiment to avoid/minimize carbonation. Figure 6 shows the thermal analysis of the resulting paste where the portlandite content was determined from the tangential method as recommended in the latest reference book [39]. The weight loss due to the water release from portlandite was $3.4 \mathrm{wt} \%$ which translates to an overall content of crystalline portlandite of $14.0 \mathrm{wt} \%$. The relatively good agreement between the amount of portlandite quantified in the in situ experiment, $12.9 \mathrm{wt} \%$, and the amount measured ex situ by thermal analysis, $14.0 \mathrm{wt} \%$, which is also close to the expected value from alite and belite reactions, demonstrate the accuracy of these in situ analyses.

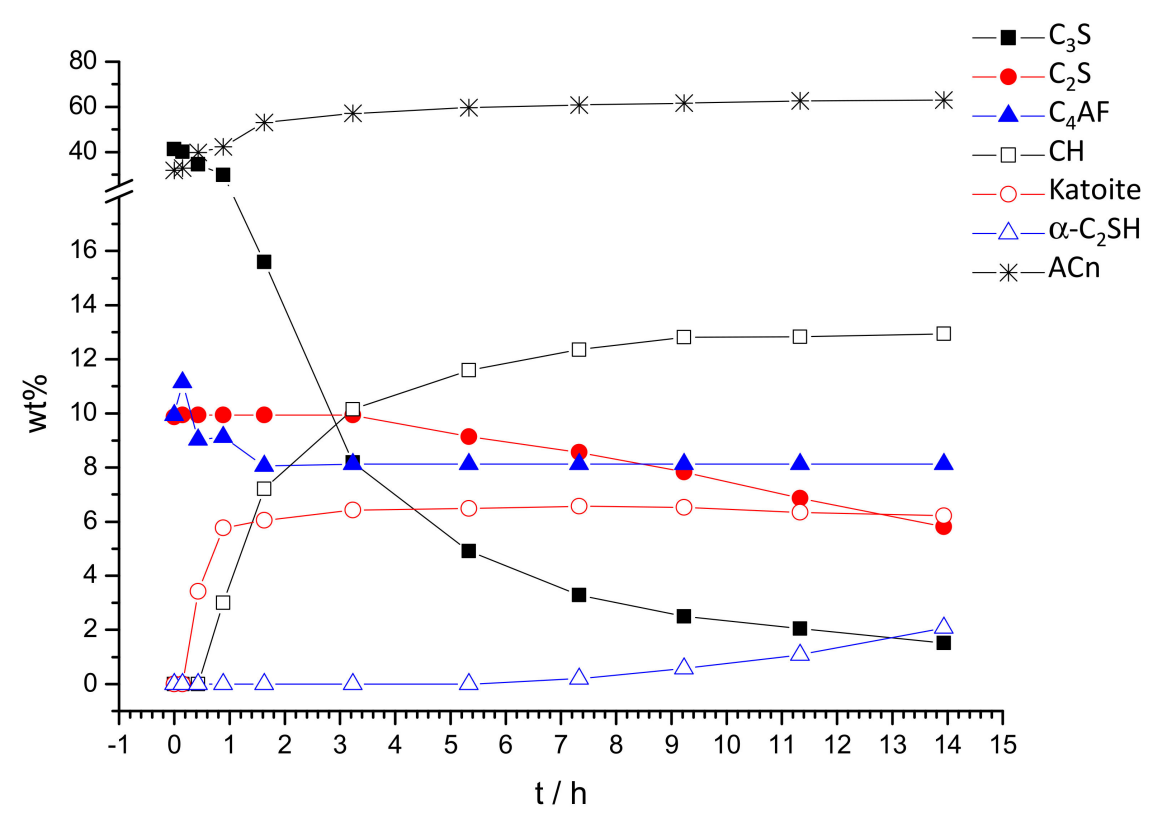

Figure 5. Re-normalized Rietveld quantitative phase analysis results for the OWC paste hydrated up to $14 \mathrm{~h}$ under 150 bars and $150{ }^{\circ} \mathrm{C}$ including the overall amorphous content.

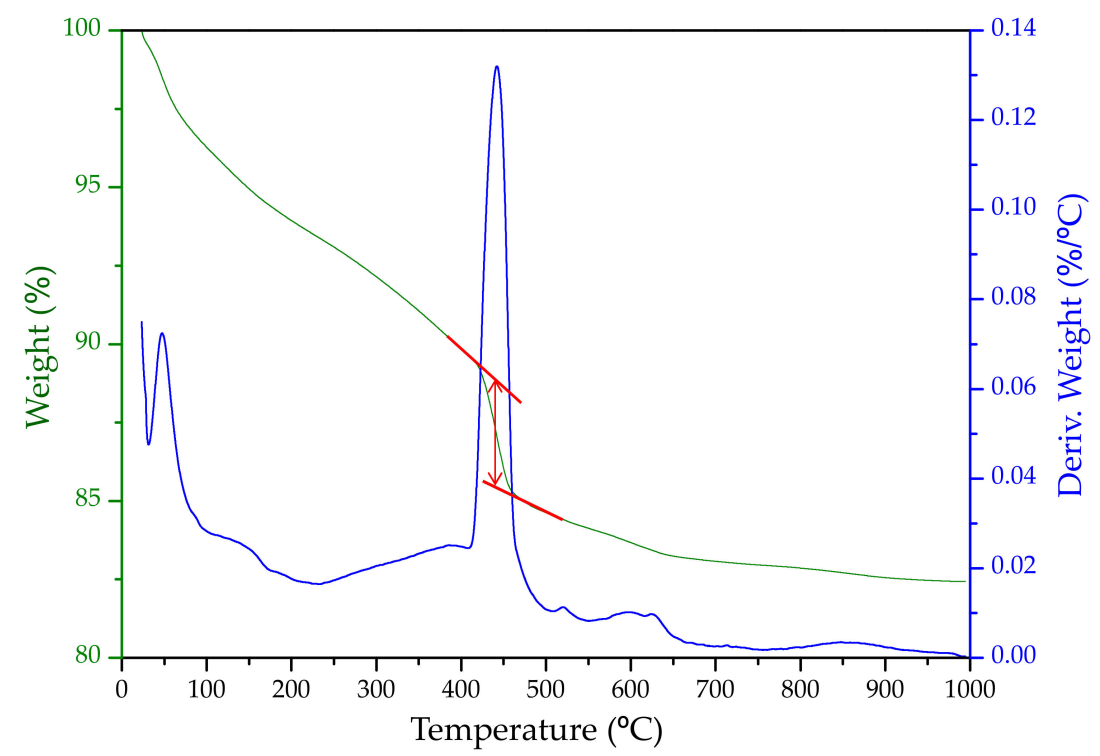

Figure 6. Ex situ thermal analysis data (weight loss-green curve, derivative of the weight loss-blue curve) for the final paste after the synchrotron experiment to quantify the overall crystalline portlandite content from the tangential method (showed in red, $3.4 \mathrm{wt} \%$ ). 
The alite reactivity determined in this study can be compared to those previously reported. Table 2 gathers our key results, which are compared to related studies, where the reactivities are extracted from the evolution of the area of single diffraction peaks. From the data reported in Table 2, it can be concluded that alite reactivity is faster in cements that in a pure alite sample, which is also the case at room temperature and atmospheric pressure. It can also be inferred that the temperature accelerates the hydration of alite more than pressure. Reports of 50\% alite reactivity in 90-150 min are quite common which is the reason to use retards in field applications. Finally and very importantly, belite reactivity has not been mentioned in any work, even with belite contents being higher than $30 \mathrm{wt} \%$ for some cements.

Table 2. Summary of the hydration details including time for $50 \%$ alite reactivity $\left[\mathrm{t}_{50} \%\left(\mathrm{C}_{3} \mathrm{~S}\right)\right]$, time for $90 \%$ alite reactivity $\left[\mathrm{t}_{50 \%}\left(\mathrm{C}_{3} \mathrm{~S}\right)\right]$ and time for $50 \%$ belite reactivity $\left[\mathrm{t}_{50} \%\left(\mathrm{C}_{2} \mathrm{~S}\right)\right]$. n.r. stands for not reported.

\begin{tabular}{|c|c|c|c|c|c|c|c|c|c|}
\hline $\begin{array}{l}\text { Type of } \\
\text { Sample }\end{array}$ & $\begin{array}{l}\text { Blaine } \\
/ \mathrm{m}^{2} / \mathrm{kg}\end{array}$ & $\begin{array}{c}\text { w/c Mass } \\
\text { Ratio }\end{array}$ & $\mathrm{T} /{ }^{\circ} \mathrm{C}$ & $\mathrm{P} /$ Bars & $\begin{array}{c}t_{50 \%}\left(C_{3} S\right) / \\
\min \end{array}$ & $\begin{array}{c}t_{90 \%}\left(C_{3} S\right) \\
/ h\end{array}$ & $\begin{array}{c}\mathbf{t}_{50 \%}\left(\mathrm{C}_{2} \mathrm{~S}\right) \\
/ \mathrm{h}\end{array}$ & Remarks & Ref. \\
\hline $\begin{array}{l}\text { Class } \\
\text { G-HSR }\end{array}$ & 340 & 0.47 & 150 & 150 & 98 & 6.6 & $\sim 15$ & - & This work \\
\hline Pure- $\mathrm{C}_{3} \mathrm{~S}$ & n.r. & 0.44 & 160 & 400 & n.a. & 16 & - & $\$$ & [11] \\
\hline Class G & 310 & 0.40 & 130 & $\sim 5$ & 160 & $\sim 6$ & - & \# & [40] \\
\hline Class G & n.r. & 0.412 & 80 & 400 & 150 & $>13$ & - & @ & [6] \\
\hline Class H & n.r. & 0.38 & 57 & " & “ & - & - & $\&$ & [7] \\
\hline Class A & 327 & n.r. & 60 & $\sim 1000$ & 90 & - & - & - & [10] \\
\hline
\end{tabular}

${ }^{\$}$ No kinetics data at early hydration ages are reported. ${ }^{\#} \mathrm{C}_{2} \mathrm{~S}$ or belite is not mentioned in the paper. ${ }^{\circledR}$ The cement contained $33 \mathrm{wt} \%$ of $C_{2} S$ but belite reactivity was not referred to. " $t_{50 \%}\left(C_{3} S\right)$ was $\sim 970,600,490,380,230$, and $75 \mathrm{~min}$ for 330, 470, 600, 900, 1200 and 1930 bars; respectively. \& The paste contained $0.1 \mathrm{wt} \%$ of maltodextrin retardant. The cement contained $25 \mathrm{wt} \%$ of $\mathrm{C}_{2} \mathrm{~S}$ but belite reactivity was not mentioned.

A small amount of ettringite crystallizes at a very early age, and it decomposes after 26 min of hydration at the applied pressure and temperature. In addition, katoite starts to precipitate before $26 \mathrm{~min}$ of hydration and its concentration reaches its maximum, $\sim 6.5 \mathrm{wt} \%$, close to $3 \mathrm{~h}$ of hydration. Finally, the formation of the non-ambient hydrated phases such as Jaffeite and $\alpha-\mathrm{C}_{2} \mathrm{SH}$ have also been quantified, see Table 1. The percentage of Jaffeite is very low, below $0.5 \mathrm{wt} \%$, after $14 \mathrm{~h}$ of hydration. Conversely, the amount of crystalline $\alpha-\mathrm{C}_{2} \mathrm{SH}$ is significant, close to $2 \mathrm{wt} \%$. According to the literature [12], the formation of $\alpha-\mathrm{C}_{2} \mathrm{SH}$ mainly occurs at the beginning of the cement hydration at high pressure and temperature conditions and then, this phase tends to convert into Jaffeite. These phases may form from the reaction of $\mathrm{C}-\mathrm{S}-\mathrm{H}$ gel and portlandite. These reactions could be further investigated by ex situ experiments; the synchrotron beamtime cannot be used to follow slow kinetics, as it would require too much time (in situ) experiments.

Table 1 and Figure 5 also report the ACn values. It is important to mention that the values obtained from this methodology encompass not only amorphous solid materials, but also the free water within the capillary and any crystalline phase not computed in the control file of the Rietveld fit. Figure 5 shows that ACn content increases with time due to the precipitation of large amounts of amorphous/nanocrystalline phases, mainly C-S-H gel. C-S-H gel can react at high pressure and temperature to yield crystalline phases, for instance Jaffeite, but this is not largely observed in the measured time window under the explored conditions.

\section{Conclusions}

The implementation of a new cell, specially designed to rotate under high pressure and temperature, currently up to 200 bars and $200^{\circ} \mathrm{C}$, made it possible to carry out in situ synchrotron powder diffraction studies of evolving powders. The quality of the powder diffraction data was sufficient to carry out Rietveld quantitative phase analyses in order to follow the reaction of each component in an OWC paste at 150 bars and $150{ }^{\circ} \mathrm{C}$. Chiefly, shown the alite and belite reactivities were determined. For instance, the reaction degree of alite reaches $90 \%$ after $7 \mathrm{~h}$ and that of belite was $42 \%$ at $14 \mathrm{~h}$. Furthermore, the measured crystalline portlandite content after $14 \mathrm{~h}, 12.9 \mathrm{wt} \%$, was shown to be accurate, as it 
agrees fairly well with the amount expected from the reactivity of alite and belite and with the ex situ measurement by thermal analysis of the final product.

Supplementary Materials: The following are available online at http://www.mdpi.com/1996-1944/12/12/1897/s1, Extended materials and methods, Table S1: Elemental composition of the Oil Well Portland cement Class G HSR used in this study, Table S2: Direct Rietveld Quantitative Phases Analysis of Oil Well paste after selected hydration times under 150 bars and $150^{\circ} \mathrm{C}$, Figure S1: Particle size distribution and cumulative volumetric particle size distribution for the pristine oil well cement, Figure S2: Calorimetric data. (a) Heat flow calorimetry curves and (b) Cumulative heat released for OWC paste (w/c mass ratio of 0.47$)$-blue, OWC paste (w/c mass ratio of 0.35) — green and a normal white Portland cement (w/c mass ratio of 0.35) used as reference-red, Figure S3: 2D synchrotron powder diffraction patterns of the oil well cement (a) anhydrous, and paste hydrated at 150 bars and $150{ }^{\circ} \mathrm{C}$ for (b) $1 \mathrm{~h}$ and $38 \mathrm{~min}$ and (c) $11 \mathrm{~h}$ and $22 \mathrm{~min}$. Some diffractions spots arising from the sapphire tube are highlighted.

Additional Information: All synchrotron X-ray raw data files underlying this paper, 62 patterns, can be accessed on Zenodo at http://dx.doi.org/10.5281/zenodo.2565904, and used under the Creative Commons Attribution license.

Author Contributions: This work is part of the E.F. PhD Thesis. M.A.G.A. designed the research; E.F. and J.D.Z.-G. carried out the sample preparation; E.F., M.A.G.A. and A.Y.-C. developed the cell; E.F., J.D.Z.-G. and A.G.D.1.T. performed the synchrotron experiment; A.G.D.I.T., J.D.Z.-G. and A.C. analysed the diffraction data; A.C., E.F. and M.A.G.A. wrote the paper which was revised by all authors.

Funding: This research was funded by Spanish MINECO, grant number BIA2017-82391-R which is co-funded by FEDER.

Acknowledgments: We thank Marc Malfois for his help during the experiment performed at NCD-SWEET beamline at ALBA synchrotron. We also thank Marcus Paul (Dyckerhoff $\mathrm{GmbH}$ ) for providing the OWC sample with its characterization and helpful discussions.

Conflicts of Interest: The authors declare no conflict of interest.

\section{References}

1. Ludwig, H.M.; Zhang, W. Research review of cement clinker chemistry. Cem. Concr. Res. 2015, 78, $24-37$. [CrossRef]

2. Taylor, H.F.W. Cement chemistry, 2nd ed.; Acad. Press Publisher: London, UK, 1997.

3. Scrivener, K.L.; Juilland, P.; Monteiro, P.J.M. Advances in understanding hydration of Portland cement. Cem. Concr. Res. 2015, 78, 38-56. [CrossRef]

4. Cuesta, A.; Zea-Garcia, J.D.; Londono-Zuluaga, D.; De la Torre, A.G.; Santacruz, I.; Vallcorba, O.; Dapiaggi, M.; Sanfélix, S.G.; Aranda, M.A.G. Multiscale understanding of tricalcium silicate hydration reactions. Sci. Rep. 2018, 8, 8544. [CrossRef] [PubMed]

5. Lea, F.M.; Frederick, M.; Hewlett, P.C. Lea's Chemistry of Cement and Concrete, 4th ed.; Elservier Butterworth-Heinemann: Oxford, UK; pp. 783-840.

6. Jupe, A.C.; Wilkinson, A.P.; Funkhouser, G.P. Oil-Well Cement and C3S Hydration Under High Pressure as Seen by In Situ X-Ray Diffraction, Temperatures $\leq 80^{\circ} \mathrm{C}$ with No Additives. J. Am. Ceram. Soc. 2011, 94, 1591-1597. [CrossRef]

7. Jupe, A.C.; Wilkinson, A.P.; Funkhouser, G.P. The effect of pressure on tricalcium silicate hydration at different temperatures and in the presence of retarding additives. Cem. Concr. Res. 2012, 42, 1083-1087. [CrossRef]

8. Lin, F.; Meyer, C. Hydration kinetics modeling of Portland cement considering the effects of curing temperature and applied pressure. Cem. Concr. Res. 2009, 39, 255-265. [CrossRef]

9. Pang, X.; Meyer, C.; Darbe, R.; Funkhouser, G.P. Modeling the Effect of Curing Temperature and Pressure on Cement Hydration Kinetics. ACI Mater. J. 2013, 110, 137-148.

10. Ma, S.; Yu, T.; Wang, Y.; Chaouche, M.; Kawashima, S. Phase Evolution of Oil Well Cements with Nano-additive at Elevated Temperature/Pressure. ACI Mater. J. 2016, 113, 571-578. [CrossRef]

11. Bresson, B.; Meducin, F.; Zanni, H.; Noik, C. Hydration of tricalcium silicate (C3S) at high temperature and high pressure. J. Mater. Sci. 2002, 37, 5355-5365. [CrossRef]

12. Meducin, F.; Zanni, H.; Noik, C.; Hamel, G.; Bresson, B. Tricalcium silicate (C3S) hydration under high pressure at ambient and high temperature $\left(200^{\circ} \mathrm{C}\right)$. Cem. Concr. Res. 2008, 38, 320-324. [CrossRef]

13. Palou, M.; Živica, V.; Ifka, T.; Boháč, M.; Zmrzlý, M. Effect of hydrothermal curing on early hydration of G-Oil well cement. J. Therm. Anal. Calorim. 2014, 116, 597-603. [CrossRef] 
14. Palou, M.T.; Šoukal, F.; Boháč, M.; Šiler, P.; Ifka, T.; Živica, V. Performance of G-Oil Well cement exposed to elevated hydrothermal curing conditions. J. Therm. Anal. Calorim. 2014, 118, 865-874. [CrossRef]

15. Jupe, A.C.; Wilkinson, A.P.; Luke, K.; Funkhouser, G.P. Class H cement hydration at $180^{\circ} \mathrm{C}$ and high pressure in the presence of added silica. Cem. Concr. Res. 2008, 38, 660-666. [CrossRef]

16. Kuzielová, E.; Žemlička, M.; Másilko, J.; Palou, M.T. Pore structure development of blended G-oil well cement submitted to hydrothermal curing conditions. Geothermics 2017, 68, 86-93. [CrossRef]

17. Kuzielová, E.; Žemlička, M.; Másilko, J.; Palou, M.T. Development of G-oil well cement phase composition during long therm hydrothermal curing. Geothermics 2019, 80, 129-137. [CrossRef]

18. Aranda, M.A.G. Recent studies of cements and concretes by synchrotron radiation crystallographic and cognate methods. Crystallogr. Rev. 2016, 22, 150-196. [CrossRef]

19. Fraga, E.; Yáñez, A.; Zea-Garcia, J.D.; De la Torre, Á.G.; Cuesta, A.; Valcárcel-Fernández, R.; Farré-París, F.; Malfois, M.; Aranda, M.A.G. High pressure and temperature spinning capillary cell for in situ synchrotron X-ray powder diffraction. J. Synchrotron Radiat. 2019, 26. [CrossRef]

20. Jupe, A.C.; Wilkinson, A.P. Sample cell for powder x-ray diffraction at up to 500 bars and $200{ }^{\circ}$ C. Rev. Sci. Instrum. 2006, 77, 113901. [CrossRef]

21. Ashiotis, G.; Deschildre, A.; Nawaz, Z.; Wright, J.P.; Karkoulis, D.; Picca, F.E.; Kieffer, J. The fast azimuthal integration Python library: pyFAI. J. Appl. Crystallogr. 2015, 48, 510-519. [CrossRef]

22. Von Dreele, R.B.; Larson, A.C. General structure analysis system (GSAS). Los Alamos Natl. Lab. Rep. LAUR 2004, 748, 86-748.

23. Thompson, P.; Cox, D.E.; Hastings, J.B. Rietveld Refinement of Debye-Scherrer Synchrotron X-ray Data from $\mathrm{A} 1_{2} 0_{3}$. J. Appl. Crystallogr. 1987, 20, 79-83. [CrossRef]

24. Aranda, M.A.G.; De la Torre, A.G.; Leon-Reina, L. Rietveld Quantitative Phase Analysis of OPC Clinkers, Cements and Hydration Products. Rev. Mineral. Geochem. 2012, 74, 169-209. [CrossRef]

25. McCusker, L.B.; Von Dreele, R.B.; Cox, D.E.; Louër, D.; Scardi, P. Rietveld refinement guidelines. J. Appl. Crystallogr. 1999, 32, 36-50. [CrossRef]

26. De la Torre, A.G.; Santacruz, I.; Cuesta, A.; León-Reina, L.; Aranda, M.A.G. Diffraction and crystallography applied to anhydrous cements. In Cementitious Materials: Composition, Properties, Application; Pöllmann, H., Ed.; De Gruyter Publising: Berlin, Germany, 2017.

27. De la Torre, A.G.; Aranda, M.A.G. Accuracy in Rietveld quantitative phase analysis of Portland cements. J. Appl. Crystallogr. 2003, 36, 1169-1176. [CrossRef]

28. De La Torre, Á.G.; Bruque, S.; Campo, J.; Aranda, M.A.G. The superstructure of C3S from synchrotron and neutron powder diffraction and its role in quantitative phase analyses. Cem. Concr. Res. 2002, 32, 1347-1356. [CrossRef]

29. Mumme, W.G.; Hill, R.J.; Bushnell-Wye, G.; Segnit, E.R. Rietveld crystal structure refinements, crystal chemistry and calculated powder diffraction data for the polymorphs of dicalcium silicate and related phases. Neues Jahrb. fuer Mineral. 1995, 169, 35-68.

30. Colville, A.A.; Geller, S. The Crystal Structure of Brownmillerite, $\mathrm{Ca}_{2} \mathrm{FeAlO}_{5}$. Acta Crystallogr. B. 1971, 27, 2311-2315. [CrossRef]

31. Takéuchi, Y.; Nishi, F. Crystal-chemical characterization of the $3 \mathrm{CaO} \cdot \mathrm{Al}_{2} \mathrm{O}_{3}-\mathrm{Na}_{2} \mathrm{O}$ solid-solution series. Cryst. Mater. 1980, 152, 259-308.

32. De la Torre, Á.G.; López-Olmo, M.-G.; Álvarez-Rua, C.; García-Granda, S.; Aranda, M.A.G. Structure and microstructure of gypsum and its relevance to Rietveld quantitative phase analyses. Powder Diffr. 2004, 19, 240-246. [CrossRef]

33. Bezou, C.; Nonat, A.; Mutin, J.-C.; Christensen, A.N.; Lehmann, M.S. Investigation of the Crystal Structure of $\gamma-\mathrm{CaSO}_{4}, \mathrm{CaSO}_{4} \cdot 0.5 \mathrm{H}_{2} \mathrm{O}$, and $\mathrm{CaSO}_{4} \cdot 0.6 \mathrm{H}_{2} \mathrm{O}$ by Powder Diffraction Methods. J. Solid State Chem. 1995, 117, 165-176. [CrossRef]

34. Petch, H.E. IUCr The hydrogen positions in portlandite, $\mathrm{Ca}(\mathrm{OH})_{2}$, as indicated by the electron distribution. Acta Crystallogr. 1961, 14, 950-957. [CrossRef]

35. Goetz-Neunhoeffer, F.; Neubauer, J. Refined ettringite $\left(\mathrm{Ca}_{6} \mathrm{Al}_{2}\left(\mathrm{SO}_{4}\right)_{3}(\mathrm{OH})_{12} \cdot 26 \mathrm{H}_{2} \mathrm{O}\right)$ structure for quantitative X-ray diffraction analysis. Powder Diffr. 2006, 21, 4-11. [CrossRef]

36. Yamnova, N.A.; Sarp, K.; Egorov-Tismenko, Y.K.; Pushcharovskii, D.Y. Crystal structure of jaffeite. Crystallogr. Rep. 1993, 38, 464-467. 
37. Sacerdoti, M.; Passaglia, E. The crystal structure of katoite and implications within the hydrogrossular group of minerals. Bull. Minéralogie 1985, 108,1-8. [CrossRef]

38. Yano, T.; Urabe, K.; Ikawa, H.; Teraushi, T.; Ishizawa, N.; Udagawa, S. Structure of $\alpha$-dicalcium silicate hydrate. Acta Crystallogr. C. 1993, 49, 1555-1559. [CrossRef]

39. Lothenbach, B.; Durdzinski, P.; De Weerdt, K. Thermogravimetric analysis. In A Practical Guide to Microstructural Analysis of Cementitious Materials; Scrivener, K., Snellings, R., Lothenbach, B., Eds.; CRC Press: Boca Raton, FL, USA, 2016.

40. Colston, S.L.; Barnes, P.; Jupe, A.C.; Jacques, S.D.M.; Hall, C.; Livesey, P.; Dransfield, J.; Meller, N.; Maitland, G.C. An in situ synchrotron energy-dispersive diffraction study of the hydration of oilwell cement systems under high temperature/autoclave conditions up to $130^{\circ} \mathrm{C}$. Cem. Concr. Res. 2005, 35, 2223-2232. [CrossRef]

(C) 2019 by the authors. Licensee MDPI, Basel, Switzerland. This article is an open access article distributed under the terms and conditions of the Creative Commons Attribution (CC BY) license (http://creativecommons.org/licenses/by/4.0/). 